\title{
Nutrients formulation to maximize Ankistrodesmus sp. microalgal cell biomass and lipid productivities
}

\author{
Wanida Pan-utai, ${ }^{1}$ Penjit Srinophakun, ${ }^{2}$ Wilasinee Inrung ${ }^{3}$ \\ ${ }^{1}$ Department of Applied Microbiology, Institute of Food Research and Product Development, Kasetsart University, \\ Chatuchak, Bangkok; ${ }^{2}$ Department of Chemical Engineering, Faculty of Engineering, Kasetsart University, Chatuchak, \\ Bangkok; ${ }^{3}$ Faculty of Agro-Industry, King Mongkut's Institute of Technology Ladkrabang, Bangkok, Thailand
}

\begin{abstract}
Ankistrodesmus sp. belongs to a group of microalgae which plays a significant role in various applications. Availability of nutrients is one of the primary factors regulating the growth and development of microalgae. Twelve experiments were run to determine the optimum media formulation of significant nutrient components for maximum biomass and lipid productivities of Ankistrodesmus sp. IFRPD 1061 cultivation using PlackettBurman design. All nutrients significantly affected biomass pro-
\end{abstract}

Correspondence: Wanida Pan-utai, Department of Applied Microbiology, Institute of Food Research and Product Development, Kasetsart University, Bangkok 10900, Thailand.

Tel. +6683.136.4554 - Fax: +662.940.6455.

E-mail: ifrwdp@ku.ac.th

Key words: Microalgae; Nutrient; Biomass; Lipid; Plackett-Burman design.

Contributions: WP and PS conceived and designed the experiments. WP and WI collected samples and performed laboratory and data analyses. WP interpreted the data and drafted the manuscript. WP, PS and WI participated in discussions and provided suggestions. All authors read and approved the final manuscript.

Conflict of interest: the authors declare no potential conflict of interest.

Acknowledgments: this study was partially supported by the Kasetsart University Research and Development Institute (KURDI), Thailand. Thanks to the Institute of Food Research and Product Development (IFRPD), Kasetsart University for supporting the research instrument. Partial aspects of the screening of nutrient composition are protected by petty patent numbers 1703000705 and 1703004929 under the Kasetsart University license.

Received for publication: 9 September 2019.

Revision received: 23 October 2019.

Accepted for publication: 25 October 2019.

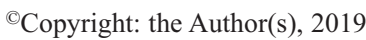

Licensee PAGEPress, Italy

Journal of Biological Research 2019; 92:8547

doi:10.4081/jbr.2019.8547

This article is distributed under the terms of the Creative Commons Attribution Noncommercial License (by-nc 4.0) which permits any noncommercial use, distribution, and reproduction in any medium, provided the original author(s) and source are credited. ductivity. Highest lipid productivity may not only necessarily originate from biomass cells with highest lipid content but also depend on nutrient formulation of culture media. Microalgal cell growth rate plays a major role in biomass and lipid production. Some nutrients including phosphorus and sodium did not significantly affect lipid productivity, therefore, optimizing nutrient contents could be applied to further scale-up microalgal production.

\section{Introduction}

Microalgae are photosynthetic cyanobacteria and eukaryotic microorganisms that grow rapidly and can live in different environments due to their unicellular or simple multicellular structure and simple growth needs. They are a potential source of many important components such as lipids, proteins, carbohydrates, and mono and polyunsaturated fatty acids. ${ }^{1}$ Microalgae produce lipids, proteins, and carbohydrates that can be processed into both biofuels and valuable co-products. They can replace large volumes of crude oil and supply demands for food supplements, animal feed, colorants, enzymes, and several other valuable chemicals. ${ }^{2}$ Commercial biomass production of feedstock can reduce nonessential nutrient composition, with large scale reductions in production costs. ${ }^{3}$ Microalgal growth depends on environmental conditions including light, temperature, carbon source, salinity, $\mathrm{pH}$, and nutrients. ${ }^{4}$ One of the most important factors affecting biomass productivity is the composition of nutrients in microalgal culture.

Many species of microalgae have been reported as potential alternative sources of biodiesel feedstock including Chlorella sp., Synechococcus sp., Schizochytrium sp., and Chlorococcum sp., ${ }^{4,5}$ Moreover, Ankistrodesmus sp. offers an interesting freshwater microalgal cultivation for fast-growing ( 2.5 doubling a day) lipid production. ${ }^{6}$ Several studies have highlighted the potential of Ankistrodesmus sp. for biodiesel production with high lipid productivity. ${ }^{7}$ Preliminary screening of potential high lipid production from several fresh microalgal strains was studied. Ankistrodesmus sp. IFRPD 1061 gave highest lipid content and productivity among other fresh microalgal strains. ${ }^{8}$ Ankistrodesmus sp. is a green phototrophic microalga which has a long crescent shape with a slight curve at both ends. ${ }^{9}$ Characteristics of cells were observed as individually clustered or twisted around each other. Ankistrodesmus sp. follows asexual reproduction, whereby parent cells divide to produce a new cell. The parental cell wall ruptures to release 1-16 spores that develop into the new cell. ${ }^{6}$ Microalgal cultivation can provide a diverse number of essential nutrients. Combining the abilities of microalgae to grow rapidly and produce more biomass than plants can 
cost-effectively satisfy the need for large-scale, high nutritional value products. ${ }^{10}$ Exploitation of microalgal strains with high biomass and lipid content is essential for sustainable biodiesel production. Ankistrodesmus sp. is an important source of lipids, pigments, and polysaccharides and is also utilized as a model organism to study cell growth and division. ${ }^{11,12}$ Microalgal cultivation to produce biomass and other products depends on several factors. Nutrients are the major environment determinations of microalgal growth, metabolism and morphology including the accumulated of lipids in the form of triacylglycerols. ${ }^{13}$ Microalgae also needs nitrogen and phosphorus as major nutrients which account for 10$20 \%$ of microalgal biomass. Moreover, other requirements for growth include macronutrients $\mathrm{Na}, \mathrm{Mg}, \mathrm{Ca}$, and $\mathrm{K}$ together with micronutrients as $\mathrm{Mo}, \mathrm{Mn}, \mathrm{B}, \mathrm{Co}, \mathrm{Fe}$, and $\mathrm{Zn}$ and also trace elements. ${ }^{4}$ Therefore, nutrients play a significant role in culture media for biomass and lipid production from microalgae. This study aimed to optimize the essential nutrient components to improve biomass and lipid productivities from Ankistrodesmus sp.

\section{Materials and Methods}

\section{Algal and inoculum preparation}

The microalga Ankistrodesmus sp. IFRPD 1061 was obtained from the Institute of Food Research and Product Development (IFRPD), Kasetsart University, Thailand. Ankistrodesmus sp. was cultured in BG-11 medium in a glass photobioreactor placed in an algal chamber under controlled temperature at $30{ }^{\circ} \mathrm{C}$, light and dark cycles of 16:8 h with 32-watt white fluorescents at light intensity of 12 Klux. Carbon dioxide was mixed at $2 \%$ with air under continuous feed through a PTFE membrane filter at a flow rate of $0.67 \mathrm{vvm}$. The BG-11 medium had the following composition $(\mathrm{g} / \mathrm{L}): \mathrm{NaNO}_{3} 1.5, \mathrm{~K}_{2} \mathrm{HPO}_{4} 0.04, \mathrm{MgSO}_{4} .7 \mathrm{H}_{2} \mathrm{O} 0.075, \mathrm{CaCl}_{2} .2 \mathrm{H}_{2} \mathrm{O}$ 0.036 , citric acid 0.006 , ammonium ferric citrate green 0.006 , EDTA. $\mathrm{Na}_{2}$ 0.001, $\mathrm{Na}_{2} \mathrm{CO}_{3} 0.02$ and micronutrients $(\mathrm{mg} / \mathrm{L}) \mathrm{H}_{3} \mathrm{BO}_{3}$ 2.68, $\mathrm{MnCl}_{2} .4 \mathrm{H}_{2} \mathrm{O} 1.81, \mathrm{ZnSO}_{4} .7 \mathrm{H}_{2} \mathrm{O} 0.22, \mathrm{Na}_{2} \mathrm{MoO}_{4} .2 \mathrm{H}_{2} \mathrm{O} 0.39$, $\mathrm{CuSO}_{4} .5 \mathrm{H}_{2} \mathrm{O} 0.08$, and $\left.\mathrm{Co}\left(\mathrm{NO}_{3}\right)_{2} \cdot 6 \mathrm{H}_{2} \mathrm{O}\right) 0.05$.
A loopful of Ankistrodesmus sp. from BG-11 agar slant was suspended in $50 \mathrm{~mL}$ of BG-11 broth medium in a glass photobioreactor. After cell growth for 3 days, the medium volume was increased to $150 \mathrm{~mL}$ for 7 days. The cells were harvested by centrifugation at $8,000 \mathrm{rpm}$ for $10 \mathrm{~min}$ and then washed twice with sterile water before being used as inoculum seed. Initial cell concentration was adjusted to optical density at $680 \mathrm{~nm}$ of 0.2 or cell dry weight at around $0.1 \mathrm{mg} / \mathrm{L}$ in culture condition.

\section{Significant nutrient component}

Plackett-Burman design ${ }^{14,15}$ was applied for screening the important nutrients for biomass and lipid production by Ankistrodesmus sp. IFRPD 1061. The experiments were designed, and data analyzed using Minitab 16 Statistical software (Minitab Inc., PA, USA). The total number of experimental runs was determined according to Plackett-Burman design at $k+1$, where $k$ represents the number of variables (media compositions) based on the first-order model used to screen significant nutrients as variables influencing biomass and lipid productivities as (Eq. 1):

$$
Y=\beta_{0}+\sum \beta_{i} X_{i}
$$

Where $Y$ is the response as the biomass and lipid productivities, $\beta_{0}$ is the model intercept, $\beta_{i}$ is the linear coefficient of the model, and $X_{i}$ is the level of an independent variable. ${ }^{14}$ Each variable is shown at two levels as high and low values by + and - , respectively (Table 1). Table 2 shows the twelve experimental design runs. The culture was cultivated in a glass photobioreactor and performed in an algal chamber under controlled temperature at $30{ }^{\circ} \mathrm{C}$, light and dark cycles of $16: 8 \mathrm{~h}$ with 32 -watt white fluorescents at light intensity of 12 Klux. Carbon dioxide was mixed at $2 \%$ with air under continuous feed through a PTFE membrane filter at a flow rate of $0.67 \mathrm{vvm} .{ }^{16,17}$ All experiments were performed in triplicate. Samples were taken every 2 days for biomass and lipid determination.

Table 1. Variables showing medium formulations used in Plackett-Burman design.

\begin{tabular}{lcccc} 
Code & Variable & Unit & High $(+1)$ & Low $(-1)$ \\
A & Medium composition & & 2.25 & 0.75 \\
B & $\mathrm{NaNO}_{3}$ & $\mathrm{~g} / \mathrm{L}$ & 0.06 & 0.02 \\
\hline $\mathrm{K}$ & $\mathrm{K}_{2} \mathrm{HPO}_{4}$ & $\mathrm{~g} / \mathrm{L}$ & 0.113 & 0.038 \\
$\mathrm{D}$ & $\mathrm{MgSO}_{4} \cdot 7 \mathrm{H}_{2} \mathrm{O}$ & $\mathrm{g} / \mathrm{L}$ & 0.054 & 0.018 \\
\hline $\mathrm{E}$ & $\mathrm{CaCl}_{2} .2 \mathrm{H}_{2} \mathrm{O}$ & $\mathrm{g} / \mathrm{L}$ & 0.009 & 0.003 \\
$\mathrm{~F}$ & $\mathrm{Citric}$ acid & $\mathrm{g} / \mathrm{L}$ & 0.009 & 0.003 \\
\hline $\mathrm{G}$ & $\mathrm{Ammonium} \mathrm{ferric} \mathrm{citrate} \mathrm{green}$ & $\mathrm{g} / \mathrm{L}$ & 0.002 & 0.001 \\
$\mathrm{H}$ & $\mathrm{EDTA}_{2} \mathrm{Na}_{2}$ & $\mathrm{~g} / \mathrm{L}$ & 0.030 & 0.010 \\
\hline $\mathrm{J}$ & $\mathrm{Na}_{2} \mathrm{CO}_{3}$ & $\mathrm{~g} / \mathrm{L}$ & 1.340 \\
& $\mathrm{H}_{3} \mathrm{BO}_{3}$ & $\mathrm{mg} / \mathrm{L}$ & 4.020 & 0.905 \\
\hline $\mathrm{K}$ & $\mathrm{MnCl}_{2} \cdot 4 \mathrm{H}_{2} \mathrm{O}$ & $\mathrm{mg} / \mathrm{L}$ & 2.715 & 0.110 \\
& $\mathrm{ZnSO}_{4} \cdot 7 \mathrm{H}_{2} \mathrm{O}$ & $\mathrm{mg} / \mathrm{L}$ & 0.330 & 0.195 \\
\hline $\mathrm{L}$ & $\mathrm{Na}_{2} \mathrm{MoO}_{4} \cdot 2 \mathrm{H}_{2} \mathrm{O}$ & $\mathrm{mg} / \mathrm{L}$ & 0.585 & 0.040 \\
& $\mathrm{CuSO}_{4} \cdot 5 \mathrm{H}_{2} \mathrm{O}$ & $\mathrm{mg} / \mathrm{L}$ & 0.120 & 0.025 \\
\hline
\end{tabular}

\footnotetext{
+ represents high values and - represents low values of each factor.
} 


\section{Analytical methods}

\section{Biomass determination}

Microalgal growth was measured by optical density at $680 \mathrm{~nm}$ using a spectrophotometer (Genesys 20, Thermo Scientific, USA), while dry cell weight was measured by gravimetric determination. Ten milliliters of sample culture was filtered through GF/C filter paper (Whatman, Maidstone, UK) and dried to constant weight at $105{ }^{\circ} \mathrm{C}$. Cell growth was calculated by the equation curve of dry cell weight concentration $(\mathrm{g} / \mathrm{L})$ with optical density at $680 \mathrm{~nm}$ as $0.6559 \mathrm{OD}_{680}\left(\mathrm{R}^{2}=0.9018\right)$. Microalgal biomass was collected every 2 days during cultivation and measured at $680 \mathrm{~nm}$ by a spectrophotometer in triplicate experiments.

\section{Lipid determination}

Lipid content was determined following the method of Bligh and Dyer (1959) with slight modification. ${ }^{18}$ Briefly, the sample culture was centrifuged at $8,000 \mathrm{rpm}$ for $10 \mathrm{~min}$, then left to settle before washing twice with distilled water. Cells were suspended in distilled water, methanol and chloroform at a ratio of 0.8:2.0:1.0 and mixed well. The mixture was ultrasonically homogenized for $15 \mathrm{~min}$ and then separated by centrifuging at 6,000 rpm for $15 \mathrm{~min}$. The lipid phase was collected, and the cell debris was extracted until the cells had no color. The lipid extract was filtered to remove debris contaminant cells and dried to constant weight at $80^{\circ} \mathrm{C}$.

\section{Results}

\section{Nutrient formulation for biomass productivity}

Screening of nutrient formulation to optimize biomass and lipid productivities from the microalgal Ankistrodesmus sp. was investigated. The screening of essential medium compositions was carried out by statistical methodology. Plackett-Burman design is a powerful technique for screening important variables. In this study, fourteen nutrient compositions were applied to screen the factors affecting biomass productivity by Ankistrodesmus sp. IFRPD 1061 using Plackett-Burman design and impacts of the various nutrient compositions for Ankistrodesmus sp. IFRPD 1061 cultivation were investigated. Table 1 shows high and low concentrations of the independent variables used to screen nutrient compositions, while Table 2 shows the twelve different experiments conducted for nutrient compositions and corresponding biomass and lipid productivities. Maximum biomass productivity varied in the range of $263-561 \mathrm{mg} / \mathrm{L} / \mathrm{d}$. Table 3 shows the effect, coefficient, $t$-value and P-value analyzed by Plackett-Burman design. Analysis of variance (ANOVA) for biomass productivity showed that all media nutrient cultivation compositions were significant. The first-order model developed by Plackett-Burman design indicated that media constituents were significant factors of Ankistrodesmus sp. IFRPD 1061 biomass productivity $\left(Q_{x}\right)$, as shown in Eq. 2:

$$
\begin{aligned}
Q_{x}(\mathrm{mg} / \mathrm{L} / \mathrm{d})= & 383.58-66.12 \mathrm{~A}-13.03 \mathrm{~B}-24.31 \mathrm{C}+6.69 \mathrm{D} \\
& +18.06 \mathrm{E}-31.62 \mathrm{~F}-20.79 \mathrm{G}+13.33 \mathrm{H}-21.51 \mathrm{~J} \\
& -8.68 \mathrm{~K}-29.47 \mathrm{~L}
\end{aligned}
$$

Parameters in this equation $(\mathrm{A}, \mathrm{B}, \mathrm{C}, \ldots)$ refer to medium composition as symbol codes described in Table 1 . The linear regression coefficient of biomass determination with adjusted $\mathrm{R}^{2}$ of $98.24 \%$ indicated that the model equation, given in un-coded units, was significant and could explain $98.24 \%$ of the variability in the response data.

Results of Plackett-Burman design obtained response optimization for maximum biomass productivity from Ankistrodesmus sp. IFRPD 1061 cultivation with nutrient compositions as follows: macronutrients, $\mathrm{NaNO}_{3} 0.75, \mathrm{~K}_{2} \mathrm{HPO}_{4} 0.02, \mathrm{MgSO}_{4} .7 \mathrm{H}_{2} \mathrm{O} 0.038$, $\mathrm{CaCl}_{2} .2 \mathrm{H}_{2} \mathrm{O}$ 0.054, citric acid 0.009 , ammonium ferric citrate green 0.003, EDTA. $\mathrm{Na}_{2} 0.001, \mathrm{Na}_{2} \mathrm{CO}_{3} 0.03$ in g/L, and micronutrients, $\mathrm{H}_{3} \mathrm{BO}_{3}$ 1.340, $\mathrm{MnCl}_{2} .4 \mathrm{H}_{2} \mathrm{O} 0.905, \mathrm{ZnSO}_{4} .7 \mathrm{H}_{2} \mathrm{O} 0.110$, $\mathrm{Na}_{2} \mathrm{MoO}_{4} .2 \mathrm{H}_{2} \mathrm{O} 0.195, \mathrm{CuSO}_{4} .5 \mathrm{H}_{2} \mathrm{O} 0.040$, and $\mathrm{Co}\left(\mathrm{NO}_{3}\right)_{2} \cdot 6 \mathrm{H}_{2} \mathrm{O}$ 0.025 in $\mathrm{mg} / \mathrm{L}$. Predicted maximum biomass productivity achieved $637.2 \mathrm{mg} / \mathrm{L} / \mathrm{d}$. Biomass productivities obtained from triplicate validation were $596.7,610.5$, and $620.1 \mathrm{mg} / \mathrm{L} / \mathrm{d}$ with mean value $609.1 \mathrm{mg} / \mathrm{L} / \mathrm{d}$. This was $4.4 \%$ less than the predicted value and the discrepancy should be regarded as acceptable.

\section{Nutrient formulation for lipid productivity}

Screening of essential medium compositions was carried out

\begin{tabular}{|c|c|c|c|c|c|c|c|c|c|c|c|c|c|}
\hline \multirow{2}{*}{ Run } & \multicolumn{11}{|c|}{ Medium composition } & & \multirow{2}{*}{$\begin{array}{l}\text { Lipid productivity } \\
\text { (mg/L/d) }\end{array}$} \\
\hline & A & B & C & D & $\mathbf{E}$ & F & G & H & $\mathrm{J}$ & K & & & \\
\hline 1 & 1 & -1 & 1 & -1 & -1 & -1 & 1 & 1 & 1 & -1 & 1 & 263.29 & 68.83 \\
\hline 2 & 1 & 1 & -1 & 1 & -1 & -1 & -1 & 1 & 1 & 1 & -1 & 382.38 & 65.69 \\
\hline 3 & -1 & 1 & 1 & -1 & 1 & -1 & -1 & -1 & 1 & 1 & 1 & 403.16 & 63.69 \\
\hline 4 & 1 & -1 & 1 & 1 & -1 & 1 & -1 & -1 & -1 & 1 & 1 & 254.03 & 80.83 \\
\hline 5 & 1 & 1 & -1 & 1 & 1 & -1 & 1 & -1 & -1 & -1 & 1 & 351.72 & 93.06 \\
\hline 6 & 1 & 1 & 1 & -1 & 1 & 1 & -1 & 1 & -1 & -1 & -1 & 353.65 & 75.48 \\
\hline 7 & -1 & 1 & 1 & 1 & -1 & 1 & 1 & -1 & 1 & -1 & -1 & 351.89 & 67.86 \\
\hline 8 & -1 & -1 & 1 & 1 & 1 & -1 & 1 & 1 & -1 & 1 & -1 & 529.64 & 57.14 \\
\hline 9 & -1 & -1 & -1 & 1 & 1 & 1 & -1 & 1 & 1 & -1 & 1 & 471.99 & 87.50 \\
\hline 10 & 1 & -1 & -1 & -1 & 1 & 1 & 1 & -1 & 1 & 1 & -1 & 299.71 & 81.53 \\
\hline 11 & -1 & 1 & -1 & -1 & -1 & 1 & 1 & 1 & -1 & 1 & 1 & 380.52 & 66.07 \\
\hline 12 & -1 & -1 & -1 & -1 & -1 & -1 & -1 & -1 & -1 & -1 & -1 & 561.04 & 45.60 \\
\hline
\end{tabular}
by statistical methodology for lipid productivity from

Table 2. Twelve Plackett-Burman designs for screening nutrient composition in biomass and lipid productivities from Ankistrodesmus sp. 
Ankistrodesmus sp. Variable nutrient compositions are shown in Table 1. Lipid productivity of Ankistrodesmus sp. from different trial experiments is shown in Table 2 . Maximum lipid productivity varied in the range of $46-93 \mathrm{mg} / \mathrm{L} / \mathrm{d}$. Table 4 shows the effect, coefficient, $t$-value and P-value analyzed by Plackett-Burman design. Analysis of variance (ANOVA) for lipid productivity indicated that all nutrient compositions of medium cultivation were significant except phosphorus and sodium carbonate. The regression model of lipid productivity $\left(Q_{p}\right)$ was developed by PlackettBurman design, as shown in Eq. 3:

$$
\begin{aligned}
Q_{p}(\mathrm{mg} / \mathrm{L} / \mathrm{d})= & 71.106+6.464 \mathrm{~A}+0.868 \mathrm{~B}-2.134 \mathrm{C}+4.241 \mathrm{D} \\
& +5.292 \mathrm{E}+5.438 \mathrm{~F}+1.308 \mathrm{G}-0.987 \mathrm{H}+1.411 \mathrm{~J} \\
& -1.946 \mathrm{~K}+5.558 \mathrm{~L}
\end{aligned}
$$

Parameters in this equation $(\mathrm{A}, \mathrm{B}, \mathrm{C}, \ldots)$ refer to medium composition as symbol codes described in Table 1 . The linear regression coefficient of lipid determination with adjusted $\mathrm{R}^{2}$ of $92.18 \%$ indicated that the model equation (given in un-coded units) was significant and could explain $92.18 \%$ of the variability in the response data. Optimization of nutrient compositions in terms of lipid productivity from Ankistrodesmus sp. IFRPD 1061 cultivation were as follows: macronutrients, $\mathrm{NaNO}_{3} 2.25, \mathrm{~K}_{2} \mathrm{HPO}_{4} 0.06$, $\mathrm{MgSO}_{4} .7 \mathrm{H}_{2} \mathrm{O} 0.038, \mathrm{CaCl}_{2} .2 \mathrm{H}_{2} \mathrm{O} 0.054$, citric acid 0.009, ammonium ferric citrate green 0.009, EDTA. $\mathrm{Na}_{2} 0.002, \mathrm{Na}_{2} \mathrm{CO}_{3} 0.01$ in $\mathrm{g} / \mathrm{L}$, and micronutrients, $\mathrm{H}_{3} \mathrm{BO}_{3} 4.020, \mathrm{MnCl}_{2} .4 \mathrm{H}_{2} \mathrm{O} 2.715$, $\mathrm{ZnSO}_{4} .7 \mathrm{H}_{2} \mathrm{O} \quad 0.110, \mathrm{Na}_{2} \mathrm{MoO}_{4} .2 \mathrm{H}_{2} \mathrm{O} 0.195, \mathrm{CuSO}_{4} .5 \mathrm{H}_{2} \mathrm{O} 0.120$, and $\mathrm{Co}\left(\mathrm{NO}_{3}\right)_{2} \cdot 6 \mathrm{H}_{2} \mathrm{O} 0.075 \mathrm{in} \mathrm{mg} / \mathrm{L}$. Theoretical maximum lipid productivity achieved $106.8 \mathrm{mg} / \mathrm{L} / \mathrm{d}$. Validation of this condition was performed in triplicate. Lipid productivities were obtained at $101.5,99.6$ and $104.5 \mathrm{mg} / \mathrm{L} / \mathrm{d}$ with an average of $101.9 \mathrm{mg} / \mathrm{L} / \mathrm{d}$. There was only a $4.5 \%$ deviation from the model-based result and this discrepancy should be regarded as acceptable.

\section{Discussion}

\begin{tabular}{|c|c|c|c|c|}
\hline \multirow[t]{2}{*}{ Variable } & \multicolumn{4}{|c|}{ Biomass productivity } \\
\hline & Effect & Coefficient & $t$-value & P-value \\
\hline A: $\mathrm{NaNO}_{3}$ & -132.24 & -66.12 & -31.77 & $0.000 *$ \\
\hline B: $\mathrm{K}_{2} \mathrm{HPO}_{4}$ & -26.06 & -13.03 & -6.26 & $0.000^{*}$ \\
\hline C: $\mathrm{MgSO}_{4} \cdot 7 \mathrm{H}_{2} \mathrm{O}$ & -48.61 & -24.31 & -11.68 & $0.000 *$ \\
\hline D: $\mathrm{CaCl}_{2} \cdot 2 \mathrm{H}_{2} \mathrm{O}$ & 13.38 & 6.69 & 3.21 & $0.004^{*}$ \\
\hline E: Citric acid & 36.12 & 18.06 & 8.68 & $0.000 *$ \\
\hline F: Ammonium ferric citrate green & -63.24 & -31.62 & -15.19 & $0.000^{*}$ \\
\hline G: EDTA.Na 2 & -41.58 & -20.79 & -9.99 & $0.000^{*}$ \\
\hline $\mathrm{H}: \mathrm{Na}_{2} \mathrm{CO}_{3}$ & 26.65 & 13.33 & 6.40 & $0.000^{*}$ \\
\hline $\mathrm{J}: \mathrm{H}_{3} \mathrm{BO}_{3}, \mathrm{MnCl}_{2} .4 \mathrm{H}_{2} \mathrm{O}$ & -43.03 & -21.51 & -10.34 & $0.000^{*}$ \\
\hline $\mathrm{K}: \mathrm{ZnSO}_{4} \cdot 7 \mathrm{H}_{2} \mathrm{O}, \mathrm{Na}_{2} \mathrm{MoO}_{4} \cdot 2 \mathrm{H}_{2} \mathrm{O}$ & -17.36 & -8.68 & -4.17 & $0.000^{*}$ \\
\hline L: $\mathrm{CuSO}_{4} \cdot 5 \mathrm{H}_{2} \mathrm{O}, \mathrm{Co}\left(\mathrm{NO}_{3}\right)_{2} \cdot 6 \mathrm{H}_{2} \mathrm{O}$ & -58.93 & -29.47 & -14.16 & $0.000^{*}$ \\
\hline
\end{tabular}

Microalgae can be used for several applications including food, feed, nutraceuticals and energy. Nutrient components used as

Table 3. Estimates for biomass productivity from Plackett-Burman design.

\begin{tabular}{|c|c|c|c|c|}
\hline \multirow[t]{2}{*}{ Variable } & \multicolumn{4}{|c|}{ Lipid productivity } \\
\hline & Effect & Coefficient & $t$-value & P-value \\
\hline A: $\mathrm{NaNO}_{3}$ & 12.927 & 6.464 & 10.46 & $0.000^{*}$ \\
\hline B: $\mathrm{K}_{2} \mathrm{HPO}_{4}$ & 1.735 & 0.868 & 1.40 & 0.173 \\
\hline $\mathrm{C}: \mathrm{MgSO}_{4} \cdot 7 \mathrm{H}_{2} \mathrm{O}$ & -4.269 & -2.134 & -3.45 & $0.002 *$ \\
\hline D: $\mathrm{CaCl}_{2} \cdot 2 \mathrm{H}_{2} \mathrm{O}$ & 8.481 & 4.241 & 6.86 & $0.000 *$ \\
\hline E: Citric acid & 10.585 & 5.292 & 8.56 & $0.000^{*}$ \\
\hline F: Ammonium ferric citrate green & 10.876 & 5.438 & 8.80 & $0.000^{*}$ \\
\hline G: EDTA.Na 2 & 2.616 & 1.308 & 2.12 & $0.045^{*}$ \\
\hline $\mathrm{H}: \mathrm{Na}_{2} \mathrm{CO}_{3}$ & -1.974 & -0.987 & -1.60 & 0.124 \\
\hline $\mathrm{J}: \mathrm{H}_{3} \mathrm{BO}_{3}, \mathrm{MnCl}_{2} .4 \mathrm{H}_{2} \mathrm{O}$ & 2.821 & 1.411 & 2.28 & $0.032 *$ \\
\hline $\mathrm{K}: \mathrm{ZnSO}_{4} .7 \mathrm{H}_{2} \mathrm{O}, \mathrm{Na}_{2} \mathrm{MoO}_{4} .2 \mathrm{H}_{2} \mathrm{O}$ & -3.893 & -1.946 & -3.15 & $0.004^{*}$ \\
\hline $\mathrm{L}: \mathrm{CuSO}_{4} \cdot 5 \mathrm{H}_{2} \mathrm{O}, \mathrm{Co}\left(\mathrm{NO}_{3}\right)_{2} \cdot 6 \mathrm{H}_{2} \mathrm{O}$ & 11.115 & 5.558 & 8.99 & $0.000^{*}$ \\
\hline
\end{tabular}

*Significant at $5 \%$ level $(\mathrm{P}<0.05)$.

Table 4. Estimates for lipid productivity from Plackett-Burman design. 
the culture medium are significant factors for biomass and intracellular bio-products. Microalgae have high photosynthetic efficiency, growth rate and biomass yield; they do not require arable land, making them superior potential biofuel candidates. ${ }^{19}$ Several factors affect microalgal cultivation and product production. Variation in culture media compositions changes the biochemical composition of microalgal accumulation for valuable products such as lipids, carbohydrates, proteins, and pigments. Different media have varying nutrient quantities that can significantly change the quantity of cell biomass produced during cultivation. ${ }^{20}$ Previous studies indicated that different media compositions prominently affected the morphology of Ankistrodesmus falcatus, whereas cultivation in BG-11 medium gave normal morphology. ${ }^{21}$ Increase in cell volume and cell wall thickness of nutrient-limited algae may reflect storage of proteins, carbohydrates and lipids as a result of delayed cell division. ${ }^{21}$ Both macronutrients and micronutrients are important for microalgal growth and lipid intracellular accumulation. Nitrogen is a constituent of protein synthesis and important for cell division and growth of microalgae. A metabolic balance exists between the rate of carbon fixation and rate of nitrogen assimilation under sufficient nitrogen concentrations in a culture medium. ${ }^{22,23}$ Phosphorus is an important nutrient for microalgal growth as it plays a significant role in cellular metabolic processes related to energy transfer, signal transduction, photosynthesis and respiration. ${ }^{24,25}$

Our results validated that optimum nutrient formulation of media culture to maximize Ankistrodesmus sp. biomass productivity involved nitrogen, phosphorus and magnesium as macronutrients at reduced quantities than the BG-11 standard formulation. Previous studies on different culture media regarding biomass productivity determined that growth rate of Ankistrodesmus falcatus was the highest in BG-11 media compared with BBM, CHU-10 and ZM. ${ }^{21}$ However, optimum biomass productivity from our results showed higher values than $6.14 \mathrm{mg} / \mathrm{L} / \mathrm{d}$. Moreover, production costs of $\mathrm{ZM}$ and $\mathrm{CHU}-10$ are higher than BG-11 medium due to excess quantity of sodium bicarbonate and other nutrient sources, especially micronutrients. ${ }^{21}$ Therefore, the optimum medium provided the minimum quantity of nutrients to support the maximum growth of Ankistrodesmus sp.

The accessibility of nutrients is one of the main factors coordinating the growth and biochemical accumulation of microalgae. Cell growth rate and biomass productivity also play important roles in determining microalgal lipid productivity. Therefore, it becomes important to optimize nutrient appropriation to achieve the optimum lipid productivity. A similar study found no significant differences in total lipid in cells grown in BG-11 and CHU-10, while CHU-11 had higher production cost than BG-11. Optimum nutrient composition for lipid production gave $\mathrm{Mg}, \mathrm{Na}, \mathrm{Zn}$ and $\mathrm{Mo}$ at less than BG-11 standard medium. These nutrients induce microalgae to undergo secondary growth and increase lipid concentration. Moreover, $\mathrm{Mg}$ serves as the central atom of the chlorophyll molecule and plays a critical role during photosynthetic activity while also synthesizing genetic material. ${ }^{26}$ Previous results reported magnesium sulfate as a major component affecting lipid productivity of Botryococcus braunii and starvation of $\mathrm{Mg}$ showed increasing lipid content for a short time period from Chlorella vulgaris and Scenedesmus obliquus. ${ }^{27,28}$ Phosphorus starvation is widely recognized as the main lipid inducer for green microalgal species. ${ }^{29}$ Our results were similar to previous reports that phosphorus was not essential in the medium composition. Algal growth can be promoted by gas feeds which increase $\mathrm{CO}_{2}$ algal bioavailability. ${ }^{30}$ Thus, $\mathrm{Na}_{2} \mathrm{CO}_{3}$ is unnecessary in medium composition for lipid production due to Ankistrodesmus sp. cultivation under continuous $\mathrm{CO}_{2}$ gas feed. Hence, optimum nutrients in culture media should be improved for Ankistrodesmus sp. IFRPD 1061 microalgae to achieve high biomass and lipid productivities.

\section{Conclusions}

Nutrients play an important role in medium formulation to achieve maximum accumulated biochemical composition of microalgae and they can be applied to scale-up microalgal production. Maximum biomass and lipid productivities from optimum nutrient content in the culture medium were improved for Ankistrodesmus sp. IFRPD 1061. All nutrients significantly affected biomass productivity, whereas phosphorus, and Na did not significantly affect lipid productivity. However, further investigations are necessary to develop mixotrophic microalgal cultivation processes for Ankistrodesmus sp. biomass production by adding chemicals to induce stress lipid accumulation as the second stage.

\section{References}

1. Abd El Aty AA, Wehaidy HR, Mostafa FA. Optimization of inulinase production from low cost substrates using Plackett-Burman and Taguchi methods. Carbohydr Polym 2014;102:261-8.

2. Bhalamurugan GL, Valerie O, Mark L. Valuable bioproducts obtained from microalgal biomass and their commercial applications: a review. Environ Engin Res 2018;23:229-41.

3. Aishvarya V, Pradhan N, Nayak RR, et al. Enhanced inorganic carbon uptake by Chlorella sp. IMMTCC-2 under autotrophic conditions for lipid production and $\mathrm{CO}_{2}$ sequestration. J Appl Phycol 2012;24:1455-63.

4. Khan MI, Shin JH, Kim JD. The promising future of microalgae: current status, challenges, and optimization of a sustainable and renewable industry for biofuels, feed, and other products. Microb Cell Factor 2018;17:36.

5. Mondal M, Goswami S, Ghosh A, et al. Production of biodiesel from microalgae through biological carbon capture: a review. 3 Biotech 2017;7:99.

6. Sukkrom K, Bunnag B, Powtongsook S, et al. Biomass and lipid enhancement in Ankistrodesmus sp. cultured with reused and minimal nutrients media. Prep Biochem Biotechnol 2016;46:467-73.

7. Do Nascimento M, Dublan M de los A, Ortiz-Marquez JCF, Curatti L. High lipid productivity of an AnkistrodesmusRhizobium artificial consortium. Bioresour Technol 2013;146:400-7.

8. Singh P, Guldhe A, Kumari S, et al. Investigation of combined effect of nitrogen, phosphorus and iron on lipid productivity of microalgae Ankistrodesmus falcatus KJ671624 using response surface methodology. Biochem Eng J 2015;94:22-9.

9. Chonsongkram J, Pan-utai W, Tareen AK, et al. Screening of high-lipid content microalgae for biodiesel production. The 26th Annual Meeting of the Thai Society for Biotechnology and International Conference, Thailand; 2014. pp. 13-20.

10. Lananan F, Mohd Yunos FH, Mohd Nasir N, et al. Optimization of biomass harvesting of microalgae, Chlorella sp. utilizing auto-flocculating microalgae, Ankistrodesmus sp. as bio-flocculant. Int Biodeter Biodegr 2016;113:C391-6.

11. Coêlho D de F, Tundisi LL, Cerqueira KS, et al. Microalgae: cultivation aspects and bioactive compounds. Braz Arch Biol Technol 2019;62:1-12. 
12. He Q, Yang H, Hu C. Optimizing light regimes on growth and lipid accumulation in Ankistrodesmus fusiformis $\mathrm{H} 1$ for biodiesel production. Bioresour Technol 2015;198:876-83.

13. Shaikh KM, Nesamma AA, Abdin MZ, Jutur PP. Molecular profiling of an oleaginous trebouxiophycean alga Parachlorella kessleri subjected to nutrient deprivation for enhanced biofuel production. Biotechnol Biofuels 2019; 12:182.

14. Li Y, Liu Z, Cui F, et al. Application of Plackett-Burman experimental design and Doehlert design to evaluate nutritional requirements for xylanase production by Alternaria mali ND16. Appl Microbiol Biotechnol 2007;77:285-91.

15. El-Sheekh MM, Khairy HM, Gheda SF, El-Shenody RA. Application of Plackett-Burman design for the high production of some valuable metabolites in marine alga Nannochloropsis oculata. Egypt J Aquat Res 2016;42:57-64.

16. Pan-utai W, Parakulsuksatid P, Phomkaivon N. Effect of inducing agents on growth and astaxanthin production in Haematococcus pluvialis: Organic and inorganic. Biocatal Agric Biotechnol 2017;12:152-8.

17. Bligh EG, Dyer WJ. A rapid method of total lipid extraction and purification. Can J Biochem Physiol 1959;37:911-7.

18. Kumar RR, Rao PH, Arumugam M. Lipid extraction methods from microalgae: a comprehensive review. Front Energy Res $2015 ; 2: 61$

19. Demirbas A, Fatih Demirbas M. Importance of algae oil as a source of biodiesel. Energy Conv Manag 2011;52:163-70.

20. Panahi Y, Khosroshahi AY, Sahebkar A, Heidari HR. Impact of cultivation condition and media content on Chlorella vulgaris composition. Adv Pharm Bull 2019;9:182-94.

21. George B, Pancha I, Desai C, et al. Effects of different media composition, light intensity and photoperiod on morphology and physiology of freshwater microalgae Ankistrodesmus falcatus - A potential strain for bio-fuel production. Bioresour Technol 2014;171:367-74.

22. Adams C, Godfrey V, Wahlen B, et al. Understanding precision nitrogen stress to optimize the growth and lipid content tradeoff in oleaginous green microalgae. Bioresour Technol 2013;131:188-94.

23. Miller R, Wu G, Deshpande RR, et al. Changes in transcript abundance in Chlamydomonas reinhardtii following nitrogen deprivation predict diversion of metabolism. Plant Physiol 2010;154:1737-52.

24. Sharma KK, Schuhmann H, Schenk PM. High lipid induction in microalgae for biodiesel production. Energies 2012;5:1532-53.

25. Chu FF, Chu PN, Shen XF, et al. Effect of phosphorus on biodiesel production from Scenedesmus obliquus under nitrogen-deficiency stress. Bioresour Technol 2014;152:241-6.

26. Dong X, Huang L, Li T, et al. The enhanced biomass and lipid accumulation in algae with an integrated treatment strategy by waste molasses and $\mathrm{Mg}^{2+}$ addition. Energy Sources Part A Recover Util Environ Eff 2019;1-10.

27. Tran HL, Kwon JS, Kim ZH, et al. Statistical optimization of culture media for growth and lipid production of Botryococcus braunii LB572. Biotechnol Bioprocess Eng 2010;15:277-84.

28. Gorain PC, Bagchi SK, Mallick N. Effects of calcium, magnesium and sodium chloride in enhancing lipid accumulation in two green microalgae. Environ Technol UK 2013;34:1887-94.

29. Zhu LD, Li ZH, Hiltunen E. Strategies for lipid production improvement in microalgae as a biodiesel feedstock. BioMed Res Int 2016;8792548.

30. Saifuddin N, Aisswarya K, Juan Y, Priatharsi P. Sequestration of high carbon dioxide concentration for induction of lipids in microalgae for biodiesel production. J Appl Sci 2015;1045-58. 